Article

\title{
The Impacts of Arable Land per Farmer on Water Markets in China
}

\author{
Yahua Wang ${ }^{1, *(D)}$, Maosen $\mathrm{Xu}^{1}$ and Tingju $\mathrm{Zhu}^{2}$ \\ 1 School of Public Policy and Management \& China Institute for Rural Studies, Tsinghua University, \\ Beijing 100084, China; xums17@mails.tsinghua.edu.cn \\ 2 ZJU-UIUC Institute, International Campus, Zhejiang University, Haining 314400, China; \\ tingjuzhu@intl.zju.edu.cn \\ * Correspondence: wangyahua@mail.tsinghua.edu.cn
}

Received: 2 November 2020; Accepted: 2 December 2020; Published: 7 December 2020

check for updates

\begin{abstract}
Water trading markets have been introduced in many countries as a means to alleviate water scarcity. However, the performance of water markets varies greatly across different countries, and in only very few countries do they work well. In this study, a two-sector water rights trading model is developed and applied to a case study in China. The results suggest that arable land per farmer is a key factor that affects the performance of water markets in China. This is positively correlated with traded water volume, with the market's economic efficiency, and with the social welfare the market brings. Although the model simulation ignores other factors, this problem can be solved by selecting a suitable research area. These findings suggest that water markets may be less likely to be effective in countries with small arable land per farmer.
\end{abstract}

Keywords: water rights trading model; water market performance; transaction cost; arable land per farmer

\section{Introduction}

Water resources have been overexploited to meet human demand due to economic and social development and urbanization, through digging wells, constructing reservoirs, building water diversion channels to regulate water resources within a river basin or among river basins, and so on [1,2]. Freshwater scarcity is increasingly perceived as a global systemic risk [3]. Among the various approaches to water management, market-based water allocation has become a hot topic [4]. This aims at maximizing the economic efficiency of water use by re-allocating water to where its marginal economic value is highest [5]. Water markets are increasingly proposed as a demand-management strategy to deal with water scarcity [6]. In the United States and Australia, there is strong evidence that market-based water transfers can improve water use efficiency, especially in irrigated agriculture, and make water pricing more efficient. For example, up to $86 \%$ of irrigators in a state in the southern Murray-Darling Basin had undertaken at least one water trading in 2010-2011 [7]; several other countries, including Chile, Spain and Mexico, have also adopted water markets.

However, globally, good water market performance exists in very few countries, mostly in the developed world [8]. In the Human Development Report 2006 [9], after investigating water markets in California and the effects of water markets on small farm households in Chile, the United Nations found that water markets are not an appropriate water management institution for developing countries that lack strong institutional capacity. In China, the first market-based water transfers took place in 2000. Since then transfers have occurred in more than seven provinces. But in China water markets are not generally considered highly active in terms of the number of transactions and the total amount of 
water traded. Furthermore, the government played a strong role in all of those transactions; thus, it is also regarded as a "quasi market" [8].

Why do water markets not perform very well in China? Many factors are discussed in the literature. The effective operation of water markets requires a variety of conditions as follows. (1) Clarification of what exactly water rights are in law is the most important prerequisite for water markets [10]. (2) Reasonable allocations of initial water rights are needed [11]. (3) Strong government regulation is important to overcome "market failure". The effective operation of water markets depends on a strong regulatory system [12]. (4) Social and cultural recognition is another key factor. It is found that successful water rights markets are always designed in accordance with local conventions and social consensus $[13,14]$. (5) Reasonable institutional arrangement is necessary for sustainable development of water markets [15]. (6) As instability of water allocation prevents effective market participation, sufficient hydrological knowledge is crucial that will help participants make rational judgments about market prices [16]. (7) There should be sufficient market benefits because the cost of establishing a water rights market system is high. In addition, more specific factors are discussed in the literature, including water conservancy facilities [17,18], transaction costs [19], market information [20], potential market size [21], participant characteristics [21,22], and terminal water price [23], etc. This paper focuses on the impact of arable land per farmer (ALPF) on the performance of a water market in China. The impact is tested with economic methods.

The rest of this paper is structured as follows. Section 2 gives an overview of the literature on how ALPF affects water market performance. Section 3 introduces the method and data used in this study to test that effect. Section 4 reports the results and Section 5 provides analysis. Conclusions are presented in Section 6.

\section{The Debate on the Impact of ALPF on Water Market Performance}

The relationship between natural resource endowment and economic development is a controversial issue. Some scholars think that natural resource endowment is an essential productive factor for economic development, and that it can improve productivity to some extent [24]; but Nordhaus [25] found that natural resources cannot help to achieve long-term economic growth, by empirical analysis of the price of oil, coal, land and other natural resources relative to the wage rate. As one of the most important natural resources, arable land plays a key role in agricultural production. In China, the Household Contract Responsibility System has been implemented in rural areas since 1978 , and from then on, arable land has been allocated to farmers and farmer households, leading to land fragmentation in the country. As a result, small pieces of arable land managed by individual farm households are common, and economy of scale in agricultural production generally does not exist in this circumstance. From 1983 to 2012, the ALPF changed from 0.13 ha to 0.16 ha and the average area of arable land per household is now around 0.53 ha. Furthermore, farmland in a household is usually distributed between four and five plots according to the survey conducted by the China Institute for Rural Studies of Tsinghua University. Small ALPF means small irrigation water used per farmer, and the amount of water which can be saved for trading is also small. In this context, there is no motivation for farmers to participate in water rights trade because they can get little benefit from such transactions. This suggests that small ALPF is a key point leading to poor performance of the water market in China.

The influence of arable land size on water rights has been long debated. Empirical studies which focused on farmers' landholding size have found, for example, that for intra-agricultural-sector water transfers in Spain, small farms sold water to large farms [26], and that in Victoria State within the Murry-Darling Basin in Australia, water transfers encouraged further expansion of large farms [27]. Large farms are also more responsive to policy incentives designed for land and water conservation [28-30]. In an empirical study in India, Saleth [31] found that limited natural resource endowment including ALPF seriously constrains farmers' opportunities to adopt formal water markets. Although these empirical studies of various circumstances have paid attention to the importance of 
arable land size, there is a lack of theoretical generalization on ALPF as a determining factor in water market development. In this paper we first hypothesize that ALPF is a key factor in enabling water markets, and then construct a formal model to test this.

\section{Data and Methods}

Analytical or numerical models of market-based water transfers usually maximize social welfare [32] or the utility of actors participating in the market, or minimize the cost of water transfers [22]. For example, using utility-maximizing models, Becker [33] concluded that high transaction costs are the main barrier for water markets in Israel and Spain. Water trades can take place only when the transaction costs are low enough or when most of the cost is covered by river basin organizations [34]. Transaction costs account for a considerable proportion of total costs, for example, $8 \%$ in the US, 7-23\% in Chile and 3-29\% in Australia [35]. Without transaction costs, small and middle-sized farms may benefit more from water transactions than large farms [36].

Before model construction, it is necessary to introduce some background. China is facing a challenge as water is still a major constraint on the nation's economic and social development due to the growing population, urbanization, and industrialization [37]. At the same time, there are serious water shortages, growing pollution, severity of droughts, and declining aquatic ecosystems which make the challenge more serious. In the previous water resources management system, the cost of using water was nearly zero for a long time, which caused a similar external diseconomy of "tragedy of the commons". In that situation, injudicious development and overuse of water could not be avoided and the negative impacts on the environment emerged including rivers drying up, ecosystem degradation, and environmental deterioration which exacerbated water shortages [37].

Therefore, more attention has been paid to water demand management in recent years [2]. In the International Conference on Water and the Environment in 1992, researchers from more than 100 countries discussed the official definition of water demand management, and the agreement was reached that reasonable water supply evaluation is necessary and that improvements in water demand management could improve the efficiency of water use [38]. Moreover, it was concluded in the conference that a well price mechanism for adjusting water demand and supply should be established for reasonable water resources allocation.

In China, the state council also issued relevant rules to strengthen the management of water demand and water use processes in 2012, and the price mechanism is one of the most important factors in water demand management. The essence of rational allocation of water resources under the principle of water demand management is to improve water use efficiency [2]. It includes two aspects. On the one hand, water use efficiency should be improved for every water use sector by water-saving technology and management systems. On the other hand, water resource allocation can be optimized through competition among water users. Price mechanism and market mechanism are considered as important ways to improve water efficiency and competition among water users [2]. Therefore, water rights and water markets were introduced into China's water resource management in the early 21st century.

In China, the ownership of water resources belongs to the country, and is exercised by government. Water users such as citizens, farmers, and enterprises have the right to use water resources. Water rights trade refers to the trade of the rights to use water. This is the basic institutional background in China. As for water resource management, the general idea is "total amount control and quota management". Total amount control means that the total water consumption of a region (for example, a province) must be controlled within a certain range. Quota management means that there is a clear water quota for each kind of water use in the region; for example, the water consumption for producing a unit of product in a factory must be controlled within a certain range.

The distribution process of water rights is represented in Figure 1. Firstly, the water administration department formulates a water use plan, which specifies the total amount of water used by each kind of water user. Next, water users such as industrial enterprises and the Irrigated Area Management 
Organization (IAMO) apply to the water administrative agency for a water abstract license, which gives them the right to take water, and stipulates water intake location, water intake limit, water return location and water quality. Of course, water users will pay a water resources fee. For irrigation water, the IAMO apply for a water abstract license, and then the water rights will be distributed to the village by the IAMO, and to the farmers by the village. For industry, due to the expansion of production and other reasons, industrial water users cannot meet their demand for water, and they cannot apply for more water according to water abstract licenses. However, farmers will save water through water-saving measures, and IAMO will manage the total saved water by farmers in a unified manner for water rights trade, and issue this on the water rights trading platform (such as the China Water Rights Exchange). Industrial water users will negotiate with the IAMO for water rights trade on the water rights trading platform.

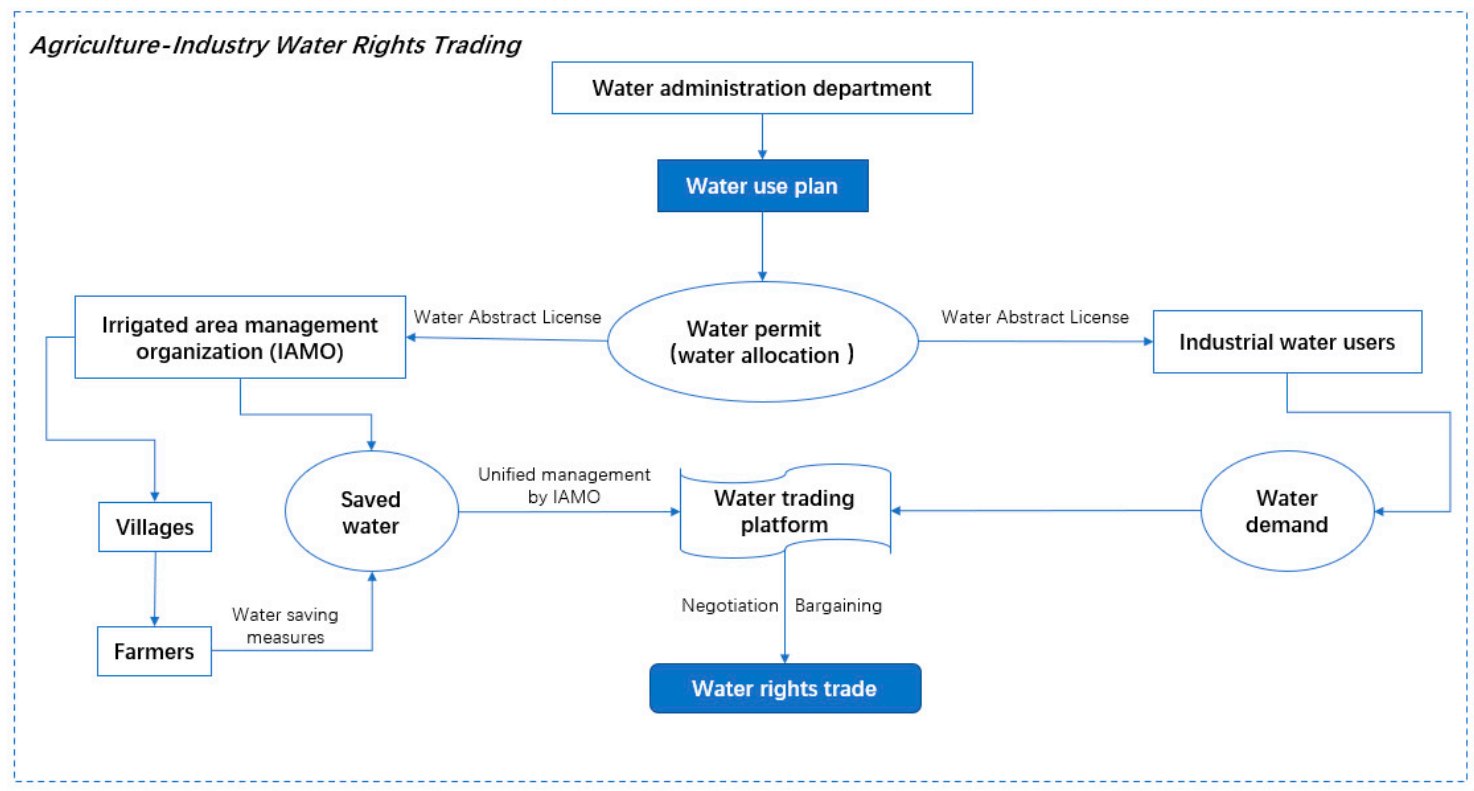

Figure 1. Mechanism of agriculture to industry water rights trading in China.

According to the mechanism of agriculture to industry water rights trading in China, in this paper a farm-level water and land management model (a two-sector water rights trading model) is built to test the hypothesis of the dominant impacts of ALPF on water market performance. This paper mainly focuses on the mechanism by which ALPF affects water market performance, along with the different levels of transaction costs. The model proposed in this study is empirically tested using data from the Inner Mongolia Autonomous Region of China.

\subsection{Two-Sector Water Rights Trading Model}

The literature on important mathematical models of water rights market are summarized in Table 1. In the model construction, resource endowment per capita such as ALPF is not included as an important influencing factor, although in theory some scholars have described the factor of "resource endowment per capita" and believe that the "resource endowment per capita" of farmers affects their behaviour in water-saving [30], and thus influences the incentive effect produced by market means. In this study, arable land per farmer (ALPF) is taken as the key variable for "resource endowment per capita", and the related mathematical model is set up to discuss how ALPF affect water market performance. 
Table 1. Important mathematical models in the literature.

\begin{tabular}{|c|c|c|c|c|}
\hline Authors & Model Principles & Research Area & Transaction Form & Results \\
\hline $\begin{array}{c}\text { Vaux, Howitt } \\
{[32]}\end{array}$ & $\begin{array}{l}\text { The utility function of } \\
\text { participants; } \\
\text { Maximize social welfare }\end{array}$ & California, USA & $\begin{array}{l}\text { Agriculture to } \\
\text { industry }\end{array}$ & $\begin{array}{l}\text { Transaction volume is } \\
4130 \times 10^{6} \mathrm{~m}^{3} \text { in } 2020 \\
\$ 219 \text { million market } \\
\text { revenue in } 2020\end{array}$ \\
\hline Becker [33] & $\begin{array}{l}\text { Maximize farmers' utility; } \\
\text { Consider transaction cost; }\end{array}$ & Israel & $\begin{array}{l}\text { Region to region; } \\
\text { agricultural } \\
\text { water rights }\end{array}$ & $\begin{array}{l}\$ 28 \text { million market revenue per } \\
\text { year, and proves transaction } \\
\text { costs significantly reduces total } \\
\text { social benefits }\end{array}$ \\
\hline Garrido [34] & $\begin{array}{l}\text { Maximization of } \\
\text { farmers' revenue }\end{array}$ & $\begin{array}{l}\text { Four irrigated areas } \\
\text { in southern Spain }\end{array}$ & $\begin{array}{l}\text { Farmer to farmer; } \\
\text { Region to region }\end{array}$ & $\begin{array}{l}\text { Transaction can happen when } \\
\text { transaction costs are very low, or } \\
\text { when } 30 \text { to } 60 \text { percent of } \\
\text { transaction costs are borne by } \\
\text { watershed institutions. }\end{array}$ \\
\hline Heaney et al. [39] & $\begin{array}{l}\text { The production function of } \\
\text { agricultural products is } \\
\text { constructed to calculate the } \\
\text { individual income of farmers } \\
\text { under water rights } \\
\text { market conditions }\end{array}$ & $\begin{array}{l}\text { Eight provinces in } \\
\text { the Yellow River } \\
\text { Basin of China }\end{array}$ & $\begin{array}{l}\text { Region to region; } \\
\text { agricultural water } \\
\text { rights }\end{array}$ & $\begin{array}{l}\$ 150 \text { million market revenue a } \\
\text { year, and increases crop yields } \\
\text { by } 1.8 \text { percent, without } \\
\text { considering transaction costs. }\end{array}$ \\
\hline $\mathrm{Li} \& \mathrm{Hu}[40]$ & $\begin{array}{l}\text { A cost-benefit model of water } \\
\text { rights market in agricultural and } \\
\text { industrial sector }\end{array}$ & General & $\begin{array}{l}\text { Agriculture to } \\
\text { industry }\end{array}$ & $\begin{array}{l}\text { Qualitatively analyzes the } \\
\text { effects of initial water rights, } \\
\text { transaction price and cost, water } \\
\text { saving cost, and water resource } \\
\text { production efficiency of } \\
\text { enterprise on water market }\end{array}$ \\
\hline Liu \& Luo [23] & $\begin{array}{l}\text { Under the water quota } \\
\text { management, the objective } \\
\text { function of farmers' water use } \\
\text { decision is constructed, and the } \\
\text { marginal cost and marginal } \\
\text { benefit curves are used to } \\
\text { solve equations. }\end{array}$ & China & Farmer to farmer & $\begin{array}{l}\text { Discusses the effects of water } \\
\text { price and transaction cost on the } \\
\text { water rights market and } \\
\text { emphasizes that the transaction } \\
\text { cost of water rights will } \\
\text { discourage farmers to } \\
\text { participate in the market. }\end{array}$ \\
\hline
\end{tabular}

Transaction costs, as an important factor in restraining water rights trading, have been emphasized in many studies [22]. Many empirical assessments point out the impact of transaction costs on environmental governance efficiency. Transaction costs in the water market have been discussed intensively in the literature. Garrick et al. [35] categorized these into static transaction costs, institutional transition costs, and institutional lock-in costs, and discussed the interactions of these three types. Bolognesi et al. [41] proposed Transversal Transaction Costs and discussed transaction costs from a dynamic perspective as institutions and policies change. Such research mainly focuses on the effect of institutions on transaction costs. However, in China the costs of water market system construction and management are mainly borne by government and industrial companies, and the coordination costs of water rights transactions between IAMOs and industrial companies are mainly borne by companies, which is the specific transaction form of China (Figure 1). Therefore, transaction costs have been assumed to be borne by industrial companies in the model. Of course, when the water market system and policy change, the transaction cost structure and how to divide it between buyers and sellers will change accordingly. The constant marginal transaction costs have been often used in the 
literature $[19,22,34,42-44]$ and in this study it is simplified as the linear correlation between transaction costs and transaction volume.

In a Chinese water market, the sellers are usually farmers, and the buyers are industrial firms. Here we adopt microeconomic theory to simulate actors' behaviour. Farms in the agricultural sector, which are highly homogeneous in terms of crops produced, are assumed to maximize the net economic gains from farming and water trading; industrial firms purchase water from farmers to expand industrial production. In the context of China, we assume that, in the water market, every farmer is an independent individual who sells water rights, while the whole industrial sector, which involves many firms, is treated as a surrogate buyer. Then two optimization models are set up for the agricultural and industrial sectors, respectively, each maximizing sectorial economic return.

To measure the economic gains of each farmer, we estimate the following equations:

$$
\max F_{i}=\left(Y_{F i}+P_{m a r} \cdot t_{i}\right)-\left(p_{F} \cdot w_{F i}+\frac{C}{N_{F}}+C_{F}\left(r_{F i}\right)\right)
$$

where $F_{i}$ is net revenue of farmer $i, Y_{F i}$ is gross crop revenue, $P_{\text {mar }}$. is water trading price between agricultural and industrial sector, $t_{i}$ is the water rights traded from farmer $i, p_{F}$ is the initial water rights price of agricultural sector, $w_{F i}$ is the initial water rights allocated to farmer $i, C$ is the total production cost for agricultural sector except for water, $N_{F}$ is rural population, and $C_{F}\left(r_{F i}\right)$ is water saving cost of farmer $i$.

The gross revenue $Y_{F i}$ is given by the Cobb Douglas function:

$$
Y_{F i}=A \cdot\left(\frac{A L}{N_{F}}\right)^{\beta_{1}} \cdot\left(\frac{K_{F}}{N_{F}}\right)^{\beta_{2}} \cdot\left(\frac{L_{F}}{N_{F}}\right)^{\beta_{3}} \cdot\left(w_{F i}\right)^{\beta_{4}}
$$

where $A$ is total factor productivity; $A L, K_{F}$ and $L_{F}$ are arable land, capital and labor of the whole agricultural sector in the research area respectively; $\beta_{1}, \beta_{2}, \beta_{3}$ and $\beta_{4}$ are output elasticities. In this study, farmers are assumed to be homogenous, which means the arable land, capital and labor possessed by each farmer are the same, and thus when calculating $Y_{F i}, A L, K_{F}$ and $L_{F}$ should be divided by $N_{F}$.

The water-saving $\operatorname{cost} C_{F}\left(r_{F i}\right)$ is estimated with a quadratic function following the empirical study in Wang [22]:

$$
C_{F}\left(r_{F i}\right)=\mathrm{a} \cdot r_{F i}^{2}+b \cdot r_{F i}+e
$$

where $a$ and $b$ are coefficients of quadratic and linear terms respectively, $r_{F i}$ is the volume of water saved by farmer $i$, and $e$ is intercept.

The industrial sector is the buyer in the water market. Without loss of generality, the entire industrial sector in the study region is treated as a single water buyer. The economic return maximization of the industrial sector is as follows:

$$
\max E=Y_{E}-\left(p_{E} \cdot W_{E}+C_{\text {other }}+C_{E}\left(R_{E}\right)+P_{\text {mar }} \cdot T+C_{\text {trade }}\right)
$$

where $E$ is net revenue of the industrial sector; $Y_{E}$ is gross revenue of industrial production; $p_{E}$ is the initial water rights price of the industrial sector; $W_{E}$ is the initial water rights allocated to the industrial sector; $C_{E}\left(R_{E}\right)$ is the water-saving cost of the industrial sector; $P_{m a r}$ is price of water purchased from the water market; $T$ is the volume of water rights traded from the agricultural sector; $C_{\text {other }}$ is production cost excluding water; and $C_{\text {trade }}$ is the transaction cost of water trading. Here we assume that the initial water rights allocated are inadequate in the industrial sector and that the transaction cost is paid exclusively by the industrial sector.

The gross revenue $Y_{E}$ is given by a Cobb Douglas function:

$$
Y_{E}=B \cdot\left(K_{E}\right)^{\partial_{1}} \cdot\left(L_{E}\right)^{\partial_{2}} \cdot\left(W_{E}\right)^{\partial_{3}}
$$


where $B$ is the total factor productivity; $K_{E}, L_{E}$, and $W_{E}$ are capital, land and water; and $\partial_{1}, \partial_{2}$ and $\partial_{3}$ are output elasticities.

The water-saving $\operatorname{cost} C_{E}\left(R_{E}\right)$ is given as:

$$
C_{E}\left(R_{E}\right)=c \cdot R_{E}^{2}+d \cdot R_{E}+\delta
$$

where $c, d$, and $\delta$ are constants, and $R_{E}$ is the volume of water saved in the industrial sector.

The transaction cost $C_{\text {trade }}$ can be assumed as a linear function $[19,22,34,42-44]$ of the volume of water traded $T$ :

$$
C_{\text {trade }}(T)=\kappa+\tau \cdot T
$$

where $\kappa$ and $\tau$ are constants. The number of farmers involved in water trading may directly affect transaction costs including information cost, communication and negotiation cost, contract signing cost, and administrative procedure cost, because the larger the number of farmers involved, the higher the cost required for information gathering and processing and for transaction arrangement [45]. If a large number of farmers are active sellers in the water market, the rural population can be used as a proxy for water sellers. In that case, the constant $\tau$ becomes a function of the rural population, $N_{F}$ :

$$
\tau=\left(\lg N_{F}\right)^{\Phi}
$$

where $\Phi$ is the transaction cost index, of which the value changes with transaction forms. There are three main transaction forms in water market, including face-to-face transaction, online transaction, and trading by water banks. Thus, Equation (7) can be written as:

$$
C_{\text {trade }}(T)=\kappa+(\lg N)^{\varphi} \cdot T
$$

Based on the principle of water balance, the constraints on the farmer side include:

$$
\begin{gathered}
U_{F}-R_{F}=Q_{F}-T \\
U_{F}-R_{F}=W_{F} \\
R_{F} \geq 0
\end{gathered}
$$

Because of the homogeneity assumption for farmers, in Equation (10) $R_{F}=N_{F} \cdot r_{F i}, W_{F}=N_{F} \cdot w_{F i}$, $T=N_{F} \cdot t_{i} ; r_{F i} \geq 0 ; t_{i} \geq 0 . W_{F}$ is the water consumption of the agricultural sector; $R_{F}$ is the volume of water-saving in the agricultural sector if water market is established; $T$ is water rights traded; $U_{F}$ is the initial water rights allocated to the agricultural sector before water market establishment; $Q_{F}$ is the initial water rights allocated to the agricultural sector after water market establishment. (In China, the initial water rights allocated to the users are controlled by the river basin authority, and in the Yellow River Basin, this is the Yellow River Conservancy Commission (YRCC)).

Similarly, water balance constraints for the industrial sector are:

$$
\begin{gathered}
U_{E}-R_{E}=Q_{E}+T \\
U_{E}-R_{E}=W_{E} \\
R_{E} \geq 0, U_{E}-Q_{E} \geq T \geq 0
\end{gathered}
$$

where $U_{E}$ is initial water rights allocated to the industrial sector before water market establishment; $R_{E}$ is water-saving in the industrial sector after water market establishment compared to before; $Q_{E}$ is initial water rights allocated to industrial sector after water market establishment; and $W_{E}$ is industrial water consumption. 
The amount of water traded and trading prices are determined by combining the first-order optimality conditions of the two optimization problems. The partial derivatives of Equation (1) with respect to $t_{i}$, and the partial derivatives of Equation (2) with respect to $T$ are:

$$
\begin{gathered}
\frac{\partial F_{i}}{\partial t_{i}}=-\frac{Y_{F(\text { money })} \cdot \beta_{4}}{W_{F}}+p_{F}-\left(2 a \cdot r_{F}+b\right)+P_{\text {mar }} \\
\frac{\partial \mathrm{E}}{\partial \mathrm{T}}=\frac{Y_{E(\text { money })} \cdot \partial_{3}}{W_{E}}-p_{E}+2 c \cdot R_{E}+d-P_{\text {mar }}-\lg ^{\varphi}\left(N_{F}\right)
\end{gathered}
$$

Let $\frac{\partial F_{i}}{\partial t_{i}}=0$ and $\frac{\partial \mathrm{E}}{\partial \mathrm{T}}=0$; by introducing Equation (10) into Equation (12), and introducing Equation (11) into Equation (13), we get:

$$
\begin{gathered}
P_{\text {mar }}=\frac{Y_{F(\text { money })} \cdot \beta_{4}}{Q_{F}-T}-p_{F}+\frac{1}{N_{F}} 2 a \cdot\left(U_{F}-Q_{F}+T\right)+b \\
P_{\text {mar }}=\frac{Y_{E(\text { money })} \cdot \partial_{3}}{Q_{E}+T}-p_{E}+2 c \cdot\left(U_{E}-Q_{E}-T\right)+d-\lg ^{\varphi}\left(N_{F}\right)
\end{gathered}
$$

Combining Equations (14) and (15) gives:

$$
T^{3}+M_{1} T^{2}+M_{2} T+M_{3}=0
$$

where:

$$
\begin{gathered}
M_{1}=-\left[\left(Q_{F}-Q_{E}\right)+\frac{k l-n h-m}{n+k}\right] ; \\
M_{2}=-\left[Q_{E} Q_{F}+\frac{\left(x_{1}+x_{2}\right)+(m+n h-k l)\left(Q_{F}-Q_{E}\right)}{n+k}\right] ; \\
M_{3}=-\frac{(m+n h-k l) Q_{E} Q_{F}+x_{1} Q_{E}-x_{2} Q_{F}}{n+k} ;
\end{gathered}
$$

In the above three equations, $m=\left(P_{E}-P_{F}+b-d+x_{3}\right) ; n=\frac{2 a}{N_{F}} ; h=U_{F}-Q_{F} ; k=2 c ; l=U_{E}-Q_{E} ;$

$$
x_{1}=Y_{F} \cdot \beta_{4} ; x_{2}=Y_{E} \partial_{3} ; \text { and } x_{3}=\lg ^{\varphi}\left(N_{F}\right) \text {. }
$$

Solving traded water volume $T$ analytically from Equation (16) is a problem of obtaining roots of a cubic equation, which leads to the following solution according to the Cardan Formula [46]:

$$
\begin{gathered}
Z_{1}=-\frac{M_{1}{ }^{2}}{3}+M_{2} \\
Z_{2}=2 \times\left(\frac{M_{1}}{3}\right)^{3}-\frac{M_{1} M_{2}}{3}+M_{3} \\
\Delta=\left(\frac{Z_{1}}{3}\right)^{3}+\left(\frac{Z_{2}}{2}\right)^{2}
\end{gathered}
$$

The solutions given in Equations (17)-(19) are determined by the value of $\Delta$. In the case study, $\Delta$ is calculated, the value is smaller than 0 , and the meaningful solution is:

$$
\mathrm{T}=2 \sqrt{-\frac{Z_{1}}{3}} \times \cos \left(\frac{\theta}{3}-\frac{2 \pi}{3}\right)-\frac{M_{1}}{3}
$$

where:

$$
\theta=\operatorname{arcCOS} \frac{-Z_{2} \times \sqrt{-27 \times Z_{1}}}{2 Z_{1}^{2}}
$$


Although the model simulation ignores other factors such as the differences among villages and IAMOs that could affect water market performance, it is a good choice to select a suitable research area where the villages and IAMOs are similar, and according to this idea, the research area is selected and the data of the model is collected. The impacts of ALPF on water markets can be better simulated and tested in this way.

\subsection{Data and Simulation}

The Inner Mongolia Autonomous Region has two characteristics that suit the analysis in this study. First, because of rapid industrial development, the demand for industrial water is strong, while in agriculture projects to save irrigation water have been pursued for years, and the water saved could be transferred to industry. Second, the ALPF of farmers is highly homogeneous, with each farm owning almost the same natural resources, such as arable land area, water, and labor. The region has been implemented a water markets policy for years to solve the problem of water scarcity. Thus, the Inner Mongolia Autonomous Region is chosen to analyze two-sector water rights trading and how ALPF affects water market performance.

Data used in this study include water prices $(P)$, output value of industry and agriculture $(Y)$, water uses $(Q$ and $U$ ), and other parameters. $U$ is the initial water rights allocated to the agricultural or industrial sector before water market establishment; $Q$ is the initial water rights allocated to the agricultural or industrial sector after water market establishment. (In China, the initial water rights allocated to the users are controlled by the river basin authority, and in the Yellow River Basin, this is the Yellow River Conservancy Commission. The water price data include agricultural and industrial water prices in the study area from the China Water Web [47]. The industrial water price used in this study is $4.36 \mathrm{yuan} / \mathrm{m}^{3}$, which is the average of the prices in 12 cities in the study area in 2014 . The agricultural water price is the average value in the Inner Mongolia Autonomous Region, estimated at $0.05 \mathrm{yuan} / \mathrm{m}^{3}$ by the government of Inner Mongolia Autonomous Region [48]. Agricultural and industrial output (i.e., $Y$ in 2014), and water use (i.e., $U$ in 2004 and $Q$ in 2014) are from the Water Resources Bulletin $[49,50]$. The first- and second-order coefficients in the water-saving cost function are from Wang [22].

The input and output elasticity of water consumption in agriculture and industry were obtained from previous studies. Maize is the main crop in the research area, so the input and output elasticity of water consumption in maize production, found to be 0.2 by Wu [51], can be taken as representative of agriculture in general. Due to the lack of region-specific elasticity estimates, the national average, which is 0.06 according to Wang and Lall [52] and $\mathrm{Xi}_{\mathrm{i}}$ [53], was used to represent elasticity in the research area. The data and elasticity inputs to the model are summarized in Table 2.

Table 2. Data and elasticity inputs to the model.

\begin{tabular}{cccc}
\hline Agriculture & Parameter Value & Industry & Parameter Value \\
\hline$Y_{F}\left(10^{8}\right.$ Yuan $)$ & 1627.85 & $Y_{E}\left(10^{8}\right.$ Yuan $)$ & 9119.79 \\
$U_{F}\left(10^{8} \mathrm{~m}^{3}\right)$ & 152.82 & $U_{E}\left(10^{8} \mathrm{~m}^{3}\right)$ & 10.38 \\
$Q_{F}\left(10^{8} \mathrm{~m}^{3}\right)$ & 137.54 & $Q_{E}\left(10^{8} \mathrm{~m}^{3}\right)$ & 19.73 \\
Elasticity $\beta_{4}$ & 0.2 & Elasticity $\partial_{3}$ & 0.06 \\
$P_{F}\left(\right.$ yuan $\left./ \mathrm{m}^{3}\right)$ & 0.05 & $P_{E}\left(\right.$ yuan $\left./ \mathrm{m}^{3}\right)$ & 4.36 \\
$a$ & 3.915 & $c$ & 1.0496 \\
$b$ & 0.033 & $d$ & 3.5913 \\
\hline
\end{tabular}

According to $\mathrm{Wu}$ [51], the transaction cost index $(\Phi)$ is around 0.6 in the U.S. We use this value to study the impact of $\Phi$ on the water market; three scenarios are analysed, with $\Phi$ values of $0.4,0.6$ and 0.8 , respectively.

The water rights trading model was programmed and solved in MATLAB using the parameter values estimated for a water market in the Inner Mongolia Autonomous Region. Input parameters 
include $Y_{F}, Y_{E}, U_{F}, U_{E}, Q_{F}, Q_{E}, P_{F}, P_{E}, \beta_{4}$, and $\partial_{3}$, and the values of $a, b, c, d$ and $N_{F}$. In the simulation, population varies from $10^{3}$ to $10^{10}$ (here we assume that the population is not possible to be smaller than $10^{3}$ and larger than $10^{10}$ ), and the basic outputs of the model are the transaction price $P_{\text {mar }}$ and the transaction water volume T. (All these terms are fully defined in Section 3.1).

According to the National Statistics Bureau of China, there were 9.15 million hectares of arable land in the Inner Mongolia Autonomous Region at the end of 2014. Table 3 shows the relationship between $N_{F}$ and ALPF in the study area. The raw database containing all input data and calculated results is provided [54].

Table 3. Relation between $N_{F}$ and arable land per farmer (ALPF). Note: ALPF is given in powers of 10; for example, if ALPF is 132 (in the range from 50 to 150), it is situated in the 100 category.

\begin{tabular}{cccccccc}
\hline$N_{\boldsymbol{F}}$ (Persons) & 1000 & 10,000 & $10^{5}$ & $10^{6}$ & $10^{7}$ & $10^{8}$ & $10^{9}$ \\
\hline ALPF (ha) & 10,000 & 1000 & 100 & 10 & 1 & 0.1 & 0.01 \\
\hline
\end{tabular}

\section{Results}

In this study, we use several indexes to measure the impacts of ALPF and transaction cost on the water market, including traded volume and traded value, index of maximum acceptable transaction cost, producer surplus, consumer surplus and total surplus of the water market. Through analysis of these indexes, we can test our hypothesis.

\subsection{Transaction Volume and Trading Volume}

Combining Equations (14) and (15) with the input parameters' value including $Y_{F}, Y_{E}, U_{F}$, $U_{E}, Q_{F}, Q_{E}, P_{F}, P_{E}, \beta_{4}, \partial_{3}, a, b, c, d$, and different levels of population $N_{F}$ and $\Phi$, transaction price $P_{\text {mar }}$ and the transaction water volume $T$ are calculated. In the case of a given value of $\Phi$, each value of $N_{F}$ corresponds to an output value of $T$ or $P_{\text {mar }}$. The results are shown in Figures 2 and 3.

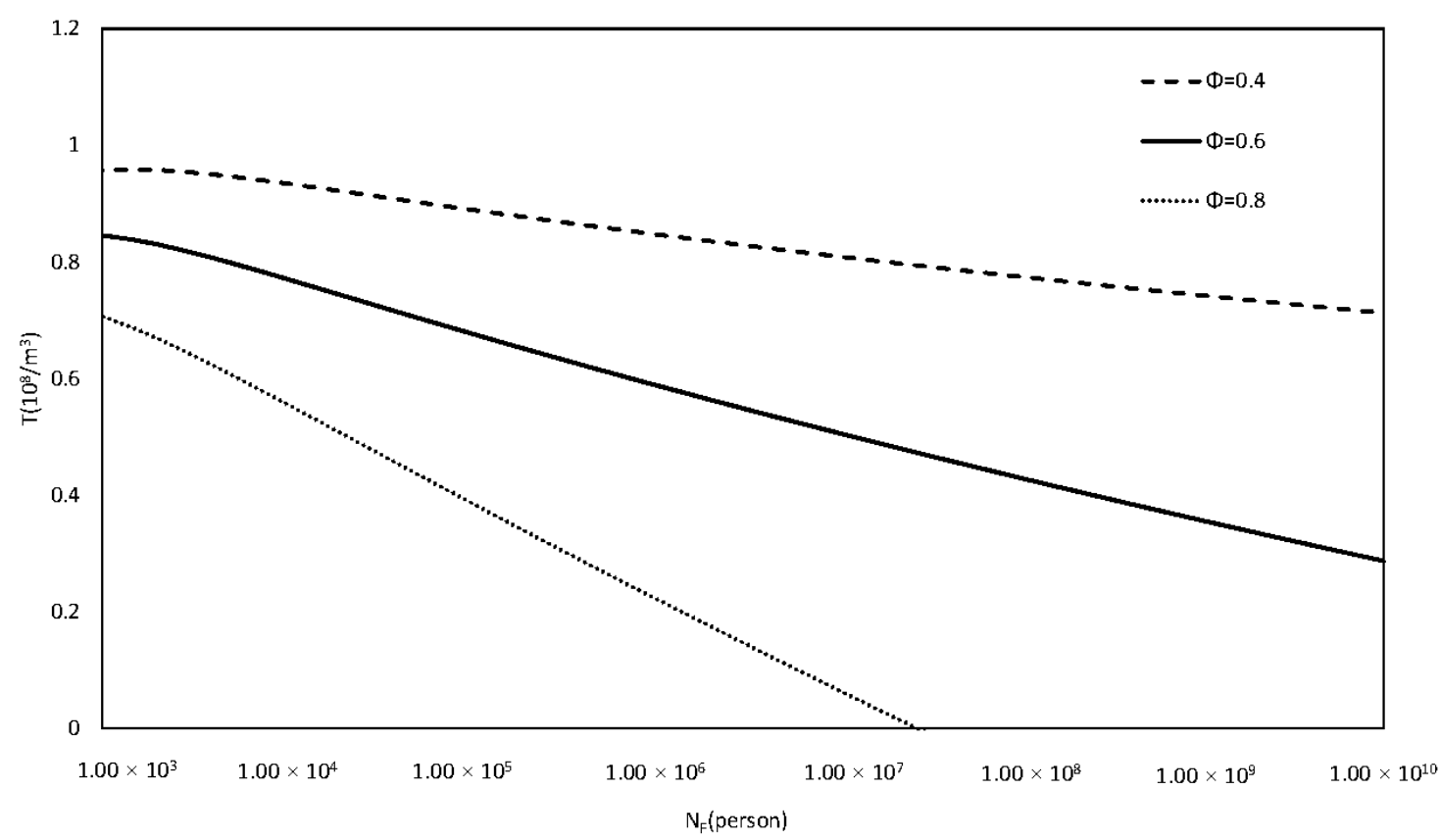

Figure 2. Relation of transaction volume $T$ to rural population $N_{F}$. 


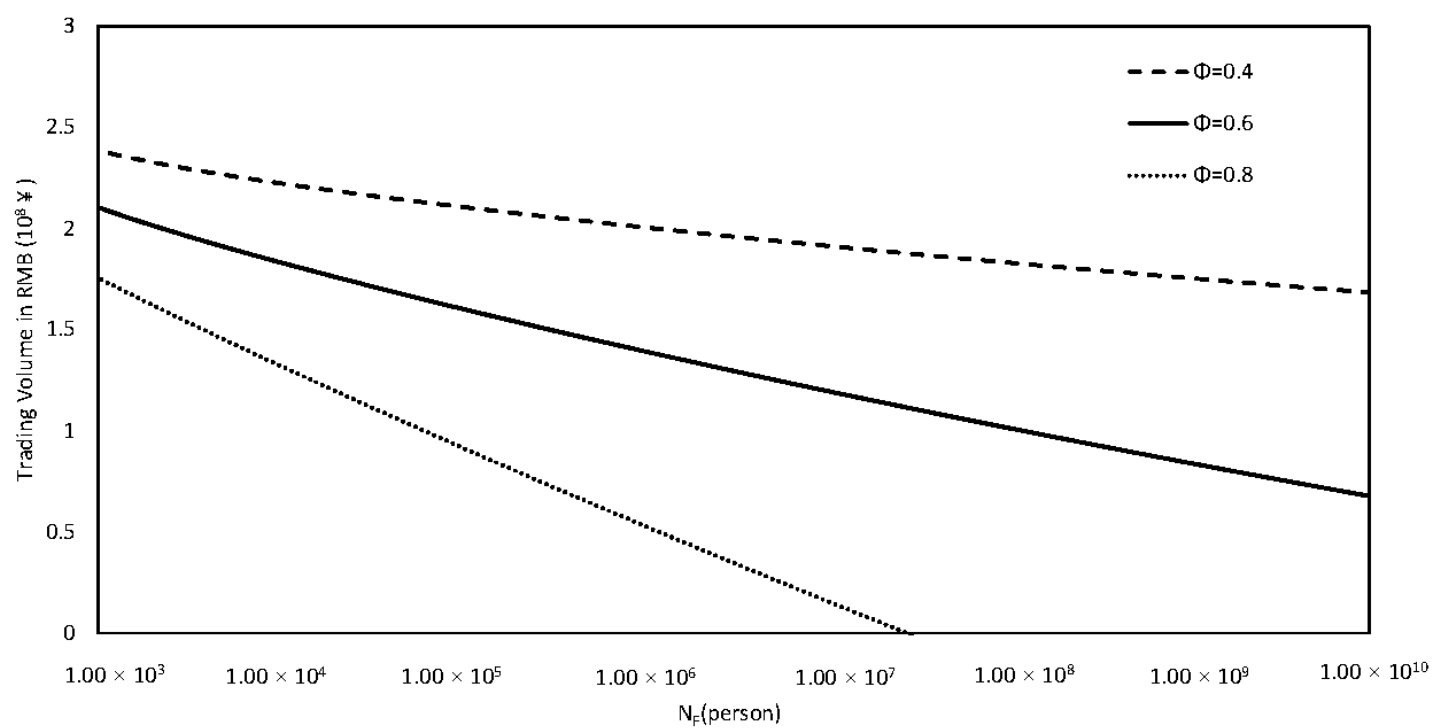

Figure 3. Relation of trading volume in RMB (Chinese money) to rural population $N_{F}$. (The trading volume is the transaction volume $T$ multiplied by the transaction price $P_{\text {mar }}$.).

\subsection{Maximum Acceptable Transaction Cost}

For Equation (16), if transaction cost index $\Phi$ is higher than a certain threshold, it could not achieve a reasonable root $T$, which means that water trading cannot occur because the transaction cost exceeds what the industrial sector can accept, and it is not worth taking part in water trading for industrial firms. That threshold is $\Phi_{\max }$. To further explore the relationship between water market performance and transaction cost, the maximum transaction cost the water market can tolerate ( $\Phi_{\max }$, the maximum value of $\Phi$ for which Equation (16) in Section 3.1 has a reasonable root $T$ ) is calculated with different values of ALPF (Figure 4).

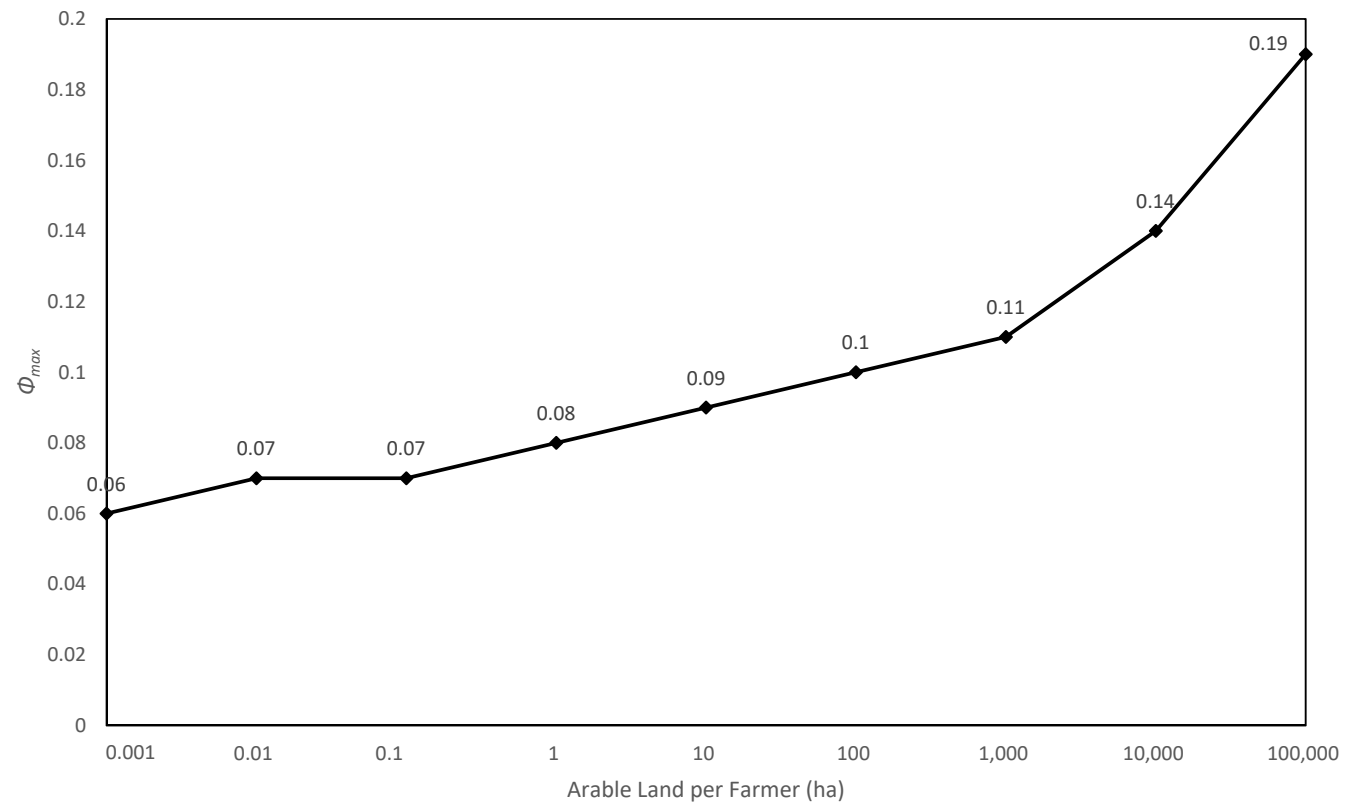

Figure 4. Relation of ALPF to maximum acceptable transaction cost index, $\Phi_{\max }$.

\subsection{Social Welfare and Economic Efficiency}

Equation (14) in Section 3.1 is the supply curve and Equation (15) is the demand curve. In the case of a given transaction cost index value $\Phi$, each level of $N_{F}$ will correspond to an equilibrium price 
and an equilibrium transaction volume. By integral operation of equilibrium price, supply curve and demand curve, producer surplus, consumer surplus and total surplus of a water market in the Inner Mongolia Autonomous Region will be calculated (Figures 5-7), which can reflect social welfare and economic efficiency.

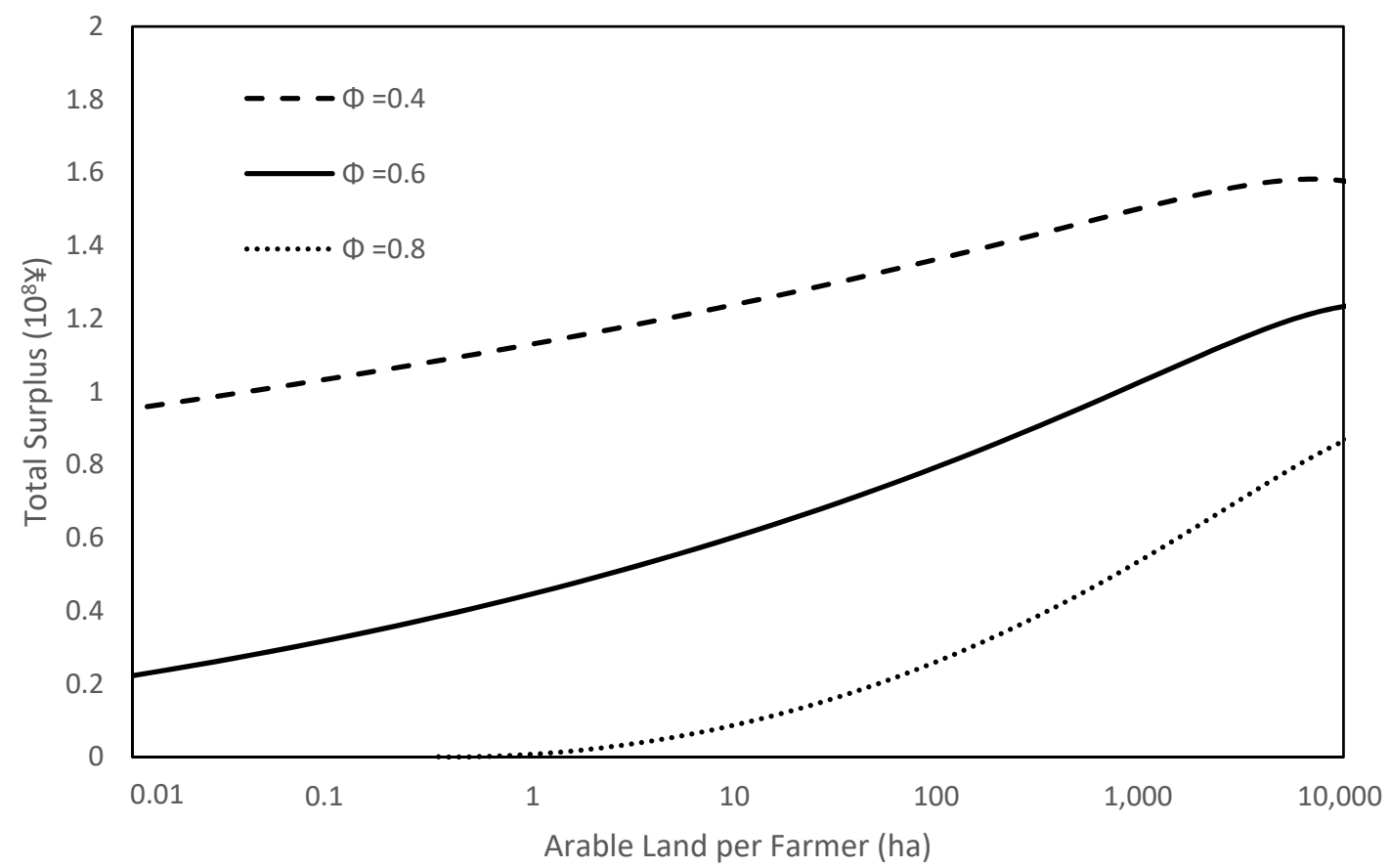

Figure 5. Relation of ALPF to total surplus. Note: Total surplus is calculated using the supply and demand curves, Equations (14) and (15) in Section 3.1.

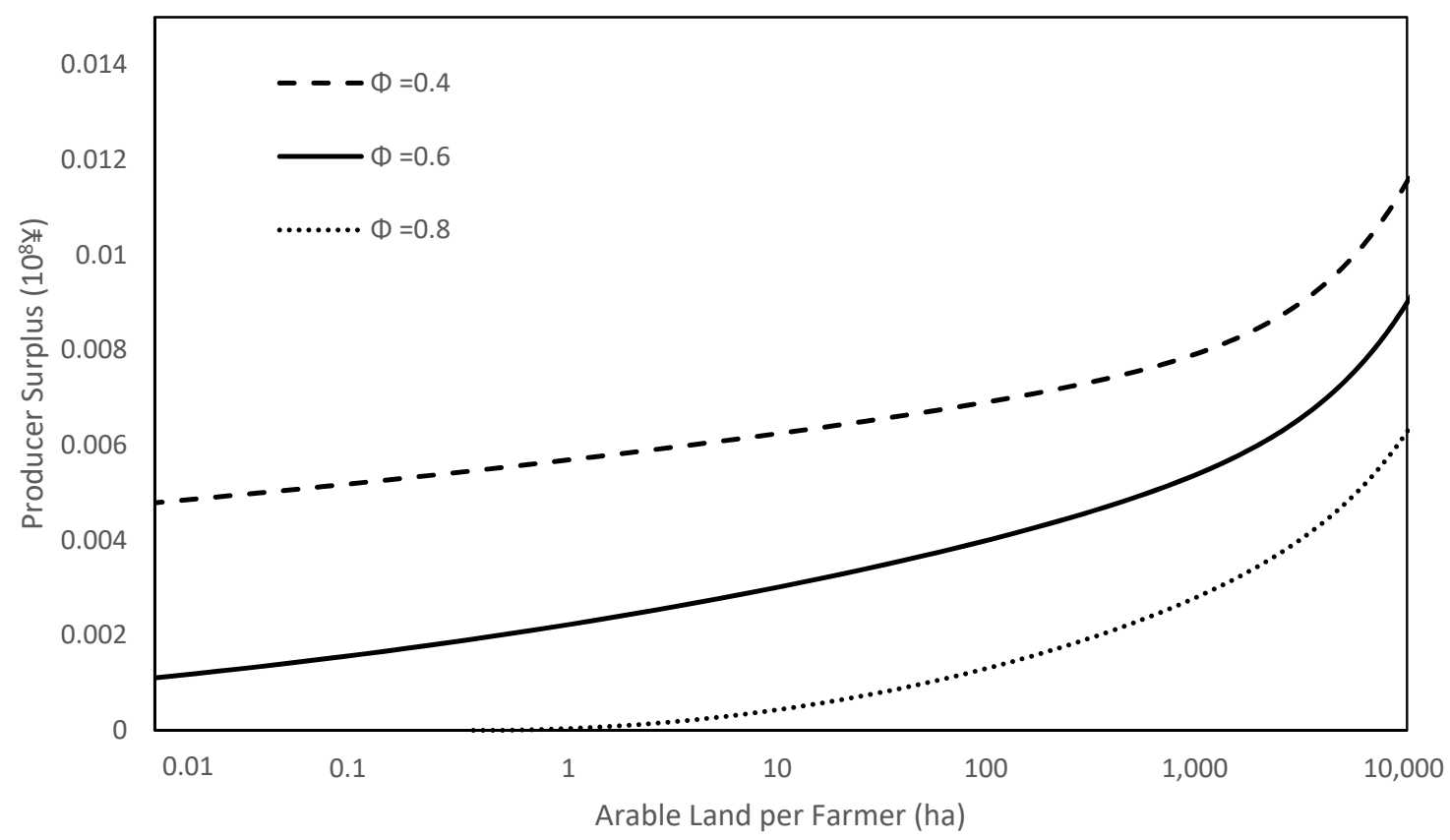

Figure 6. Relation of ALPF to producer surplus. Note: Producer surplus is calculated from the equilibrium price $P_{\operatorname{mar}}$ and the supply curve, Equation (14) in Section 3.1. 


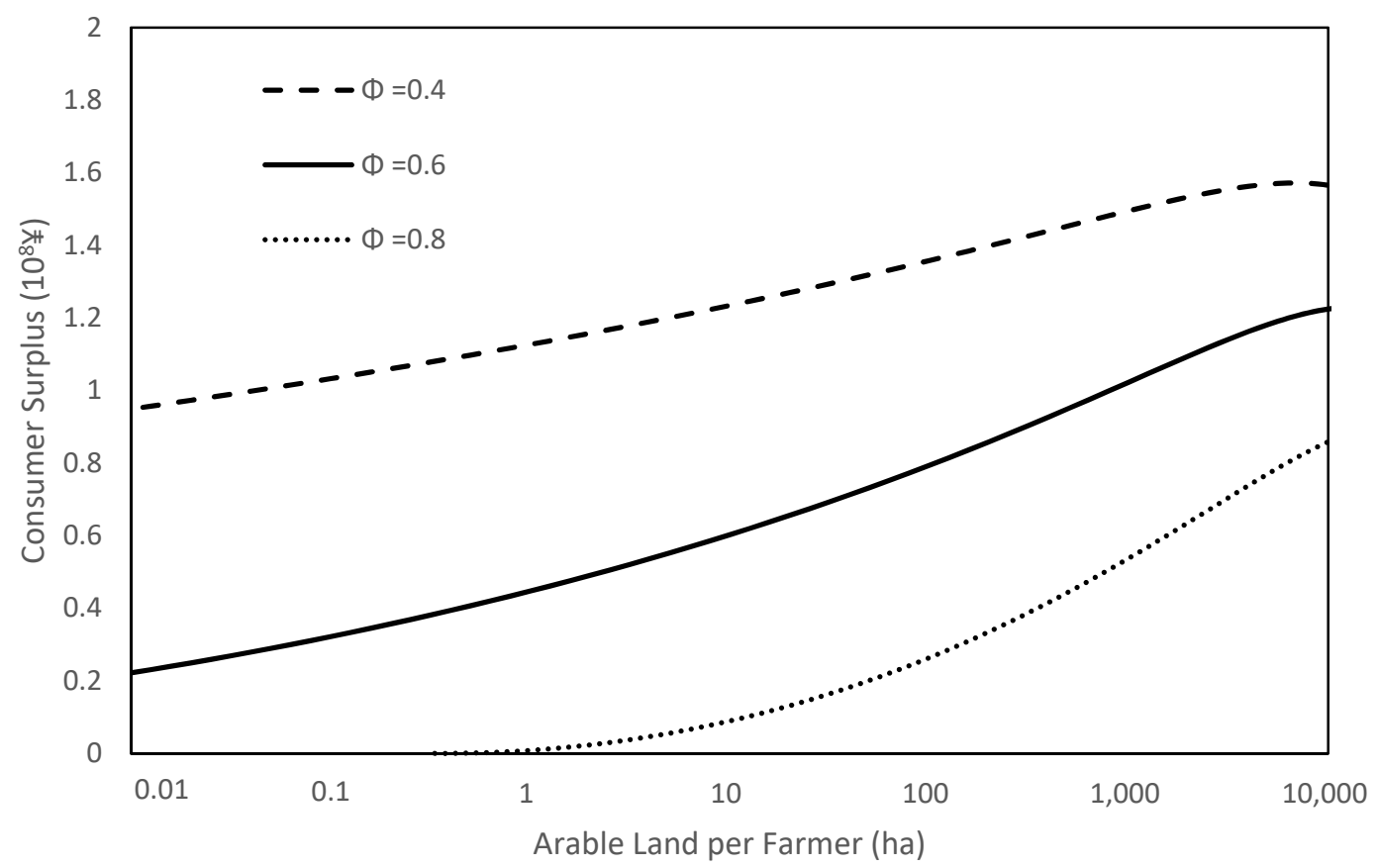

Figure 7. Relation of ALPF to consumer surplus. Note: Consumer surplus is calculated using the equilibrium price $P_{\operatorname{mar}}$ and the demand curve, Equation (15) in Section 3.1.

\section{Discussion}

In previous studies, Cason and Gangadharan [55] examined the impact of transaction costs on the environmental resource trading market, and found that, in the absence of transaction costs, the difference in initial allocation quantity (which can also be regarded as resource endowment per capita) only affects the fairness of the market, but once transaction costs are present, this will affect the final policy cost. At the same time, many scholars believe that resource endowment per capita affects farmers' response to water-saving policy measures, and arable land per farmer (ALPF) is taken as the variable for research. The specific literature is shown as follows in Table 4.

Table 4. Previous studies of ALPF.

\begin{tabular}{|c|c|c|}
\hline Author & Research Area & Effect of Arable Land on Water Management \\
\hline Amsalu \& De Graaff [28] & Ethiopia & $\begin{array}{l}\text { The larger the arable land is, the more positive the farmers will be } \\
\text { to the government's water resources policies. }\end{array}$ \\
\hline Anley et al. [29] & Western Ethiopia & $\begin{array}{l}\text { The larger the arable land is, the more active the farmers are in the } \\
\text { practice of saving water and protecting the land. }\end{array}$ \\
\hline Bekele \& Drake [30] & Ethiopia & $\begin{array}{l}\text { Farmers with larger farms have formed their own water and soil } \\
\text { conservation committees. }\end{array}$ \\
\hline Pender \& Kerr [56] & Shirapur, India & $\begin{array}{l}\text { The larger the farmland is, the more the farmers will invest in } \\
\text { saving water }\end{array}$ \\
\hline Jara-Rojas et al. [57] & Chile & $\begin{array}{l}\text { Water price policy is an effective way to incentivize the farmers to } \\
\text { save water. The government can provide subsidies or education to } \\
\text { cover the water bills of the disadvantaged groups. }\end{array}$ \\
\hline Saleth [31] & India & $\begin{array}{l}\text { Due to inadequate resource endowments per farmer, informal } \\
\text { water rights markets exist only in some parts of India. }\end{array}$ \\
\hline
\end{tabular}

The model simulation results of this study prove that ALPF and transaction cost affect water market performance and we try to analyze the theoretical connotations. The results of transaction volume and trading volume (Figures 2 and 3) demonstrate that, regardless of transaction costs, when transaction cost index $\Phi$ is kept unchanged, higher $N_{F}$ (i.e., less ALPF) reduces transaction volume $T$ and total traded value in RMB $\left(P_{\text {mar }}\right.$ times $\left.T\right)$. So there exists positive correlation between ALPF and water transaction volume. We can explain this in the context of China. Lower $N_{F}$ means that each farmer 
owns more arable land (i.e., more ALPF) because total arable land is a fixed value, therefore there will be greater water saving potential and the farmer could make more money by water transaction, thus stimulating the farmer to trade water.

In Figure 2, the curve gets steeper with greater transaction cost index $\Phi$, indicating that the higher the transaction cost, the more sensitive transaction water volume $T$ is to $N_{F}$ and ALPF (total arable land is a fixed value, i.e., $N_{F}$ times ALPF is a constant). Trading volume in RMB behaves the same way (Figure 3). We also see that holding ALPF constant, the larger the transaction cost index $\Phi$, the smaller the transaction water volume $T$. So there exists negative correlation between transaction $\operatorname{cost}$ index $\Phi$ and water transaction volume. Theoretically, if transaction costs such as information costs, which is paid for by the industrial sector exclusively, are higher, the industrial sector earns less which will discourage it from taking part in water trading, and will lead to smaller transaction volume. This study only discusses constant marginal transaction costs, but some preliminary speculations on non-linear transaction costs can be made from the simulation results. Since the transaction cost is negatively correlated with the transaction volume, if the marginal transaction cost decreases the transaction volume will increase, and market performance will be improved.

As shown in Figure 4, despite the high transaction cost, a water market can still exist with high ALPF. The trend of the curve shows that when ALPF varies from 10,000 ha to 100,000 ha, the difference in $\Phi_{\max }$ is 0.05 . However, when it varies from 0.1 ha to 1 ha, the difference is only 0.01 . Thus, smaller ALPF makes the actors in the water market more sensitive to transaction costs. If ALPF is too small, the water market will no longer be viable. So there exists positive correlation between maximum acceptable transaction cost index $\Phi_{\max }$ and ALPF. This is logical because more ALPF means greater water saving potential for farmers, and greater potential water transaction will stimulate the industrial sector to accept a higher transaction cost.

Figures 5-7 show that, as ALPF increases, the total surplus, producer surplus, and consumer surplus also increase. Obviously, lower transaction costs will bring higher total surplus, producer surplus and consumer surplus. In short, ALPF is a key factor in water rights trading. Theoretically, more ALPF will stimulate more farmers to take part in water trading because they can earn more money in the water market. For the industrial sector, when transaction costs are stable and water trading price is not high, industrial firms can expand production with more water. Then, the welfare of both sides will reach a higher level. However, higher transaction cost will discourage the industrial sector from taking part in water trading, the water saved by farmers cannot be traded and expanded production in the industrial sector will not happen, which leads to a decrease in both sides' welfare. So greater ALPF can increase the economic efficiency of the water market, while higher transaction costs can reduce it. Low transaction costs help improve social welfare.

It is less than 20 years since China introduced the water rights system. However, the construction of a water rights system and the development of a water market in many countries has been in place for many years, such as in the United States, Australia and Chile. It is a slow process whereby water markets are constructed and its rules accepted and adopted by local participants.

In some countries, especially in the United states and Australia, water rights trading systems help to improve water resources utilization efficiency and save water. Government should play a leading role in market formation. For example, in California, the government has implemented many policies and laws to encourage water rights holders to save water for trading [58], and such policies and laws conform to its historical tradition and context. From this point of view, the relationships between government and market are complementary rather than contradictory. Government creates an appropriate institutional environment for the market, and the market helps to solve problems of governance and improves efficiency.

The market mechanism will also bring some negative effects (i.e., market failures). For example, the pursuit of interests from water rights trading may result in environmentally damaging water consumption and deterioration of ecology, harm to the interests of water users in the downstream area, and encroachment on the interests of vulnerable farmers [51,59]. To solve these problems, on the one 
hand, the government needs to constantly regulate markets, and on the other hand, social organizations may need to be cultivated. Some evidence suggests that water user associations potentially improve farmer welfare, such as improvements in water delivery services, prevention of opportunistic behavior in local systems, and improvement of the financial viability of irrigation systems [60-62], and social organizations may solve the problems of market and government failures.

Based on the results of this study and the experience of international water rights markets, we believe that policy design must fully consider impacts within the actual situation, such as low ALPF in China. The relationships between government, market, and social organizations should be carefully dealt with in the specific national context.

In China, it has only been 20 years since the introduction of a market mechanism into water resources management, and relevant policies are not perfect. Some key factors such as ALPF limit the functioning of the water market mechanism, and people have not fully accepted and adapted to a water market that regulates water resources. Based on such conditions, we suggest that the government plays a leading role and builds institutions to cultivate the market and social organization in water governance. Second, market mechanisms should be carefully introduced, and the related policies and regulation designs should be based on adequate consideration of the impacts and the specific context. Third, the participation of social organizations should be introduced and serve as organizational bridges connecting the government and people.

\section{Conclusions}

This study provides a new perspective on natural resource per capita to analyze water market mechanisms in developed countries. In the study, a two-sector water rights trading model was theoretically developed and empirically simulated based on data from the Inner Mongolia Autonomous Region of China. The results offer new insights on water market development in China. First, ALPF significantly affects the performance of the water market. When ALPF is small, traded water volume is small, as are economic gains from the transactions. Second, small ALPF makes the water market more sensitive to transaction costs. Third, the smaller the ALPF, the lower the economic efficiency of the water market, and the less social welfare water rights trading can bring. Theoretically, ALPF will affect the motivation of farmers to take part in water transactions, and small ALPF could discourage them to trade water. Transaction costs will affect the ability of the industrial sector to buy water rights from farmers, and very high transaction costs may exceed what industrial firms can accept which may lead to low water rights purchase intention in the industrial sector.

In this study, we hypothesize that ALPF is a key factor in enabling water markets, and then construct a formal model to test this. The model simulation explains the mechanism of how arable land per farmer affects the water market. We adopted an economic model to simulate the water market mechanism and to observe how ALPF affects water rights trading. However, in reality, participants' behavior in water markets is affected and restricted by various objective conditions, which cannot be specifically realized in econometric models. This research mainly discusses the ignored factor (ALPF) in prior literature, and the model simulations are based on simplified conditions. There may be errors in specific values, especially for the parameters and the form of the water transaction equations, which can impact the results. However, the trial is worthwhile in researching ALPF by model simulation to fill the gap in the literature.

The results of this study provide new insights into water resource allocation, water rights and water markets. This innovative perspective on ALPF may help us explain the disparity of water market performance. The data collected from some countries can provide interesting clues. We calculate ALPF for selected countries. As shown in Figure 8, Australia, and the United States have more ALPF, and water market performance in these two countries is robust. ALPF is at a medium level in Chile compared to China, the USA (California) and Australia, and the water markets in this country perform at a moderate level. Water market performance in China is rather poor, and ALPF is small. A possible mechanism is that, for large farms in developed countries, the transaction cost of water transfers is fairly 
small compared with the value of the water being traded, while for smallholder farmers in developing countries, the share of transaction costs in the economic gains of selling or buying water can be rather high. Moreover, farmers in developed countries have better information on water infrastructure and markets than their counterparts in developing countries. As Figure 8 shows, the difference in ALPF across these countries is consistent with traded water volume (which can be regarded as a measure of water market performance).

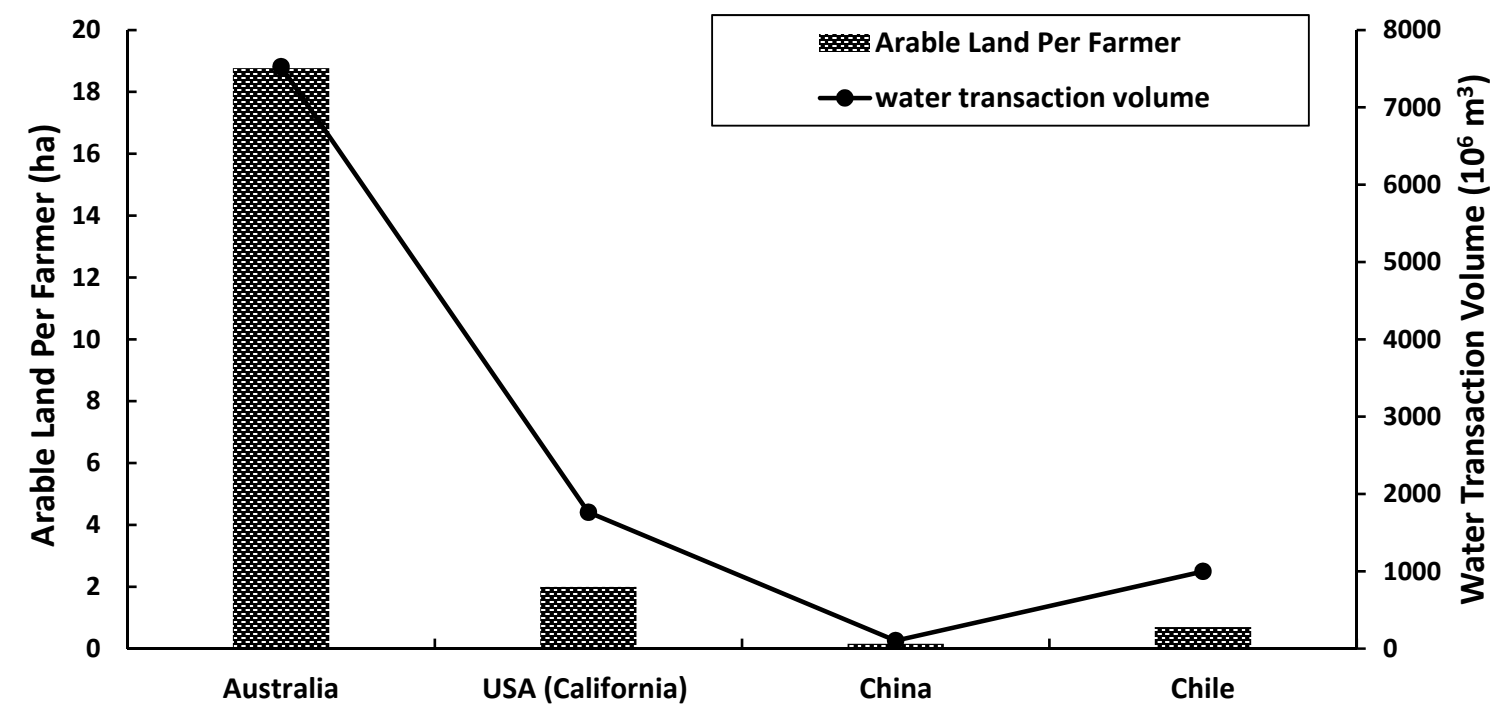

Figure 8. Transaction water volume and ALPF in developed and developing countries. Note: The data of ALPF and the transaction water volume in Australia, California, and Chile are from Wu (2015), the transaction water volume in China is from China Water Exchange (2017), and the ALPF is from $\mathrm{Wu}(2015)$.

The findings also have important implications for water policy making. For example, they imply that countries with small ALPF, such as Eastern Asian countries, including China, should be cautious about employing water markets to address water shortage. Given that context significantly affects institutional performance [63], water markets may not be a good choice in developing countries, because most of these countries have limited ALPF and poor institutional capacity. Some studies have suggested pricing mechanisms as an alternative way to introduce market effects to increase water saving in China [64]. We speculate that water pricing may be a more effective policy instrument to curb the growth of water consumption in countries with smaller ALPF.

This study inevitably has some limitations. Firstly, this research is conducted in the context of China, and all calculations and analysis are based on this context, which may cause doubt as to whether the conclusion is general. Thus, more empirical tests on the relationship between the ALPF and water trading performance in more developing countries are required. Secondly, some simplification strategies are adopted in the model such as setting linear marginal transaction cost and there may be errors in the fitting parameters. Thirdly, this study is more of a normative research than a positive research, and the mechanism is only explained from an economic point of view. It is necessary to encourage more research around this theme from other disciplines.

Author Contributions: Y.W. conducted the model development and the data collection. M.X. conducted the paper write-up and the case study. T.Z. offered guidance on the modelling work and paper revision. All authors have read and agreed to the published version of the manuscript.

Funding: This work was jointly supported by the Major Program of the National Social Sciences Foundation of China [grant number 15ZDB164]; National Natural Science Foundation of China [grant number 71573151 and 71721002]; National Key Research Program [grant number 2016YFC0401408].

Conflicts of Interest: The authors declare no conflict of interest. 


\section{References}

1. McDonald, R.I.; Weber, K.; Padowski, J.C.; Flörke, M.; Schneider, C.; Green, P.A.; Gleeson, T.; Eckman, S.; Lehner, B.; Balk, D.; et al. Water on an urban planet: Urbanization and the reach of urban water infrastructure. Glob. Environ. Chang. 2014, 27, 96-105. [CrossRef]

2. Wang, L.; Huang, Y.; Zhao, Y.; Li, H.; He, F.; Zhai, J.; Zhu, Y.; Wang, Q.; Jiang, S. Research on Optimal Water Allocation Based on Water Rights Trade under the Principle of Water Demand Management: A Case Study in Bayannur City, China. Water 2018, 10, 863. [CrossRef]

3. Mekonnen, M.M.; Hoekstra, A.Y. Four billion people facing severe water scarcity. Sci. Adv. 2016, 2, e1500323. [CrossRef] [PubMed]

4. Li, X.; Chang, F.X.; Chen, J. Summary of researches on water rights and initial water rights allocation. J. Yangtze River Sci. Res. Inst. 2011, 28, 1-9.

5. Jiang, J.Y. Economic analysis of the third-party effect of water rights trade. Water Resour. Dev. Res. 2012, 11, 48-51.

6. Wheeler, S.A.; Loch, A.; Crase, L.; Young, M.; Grafton, R.Q. Developing a water market readiness assessment framework. J. Hydrol. 2017, 552, 807-820. [CrossRef]

7. Wheeler, S.; Loch, A.; Zuo, A.; Bjornlund, H. Reviewing the adoption and impact of water markets in the Murray-Darling Basin, Australia. J. Hydrol. 2014, 518, 28-41. [CrossRef]

8. Wang, Y. How to use "two-hands force" in water management. China Water Resour. 2014, 10, 4-6.

9. Watkins, K. Human Development Report 2006-Beyond Scarcity: Power, Poverty and the Global Water Crisis; United Nations Development Programme: New York, NY, USA, 2006.

10. Anderson, T.L. Continental Water Marketing; Pacific Research Institute for Public Policy: San Francisco, CA, USA, 1994.

11. Bekchanov, M.; Bhaduri, A.; Ringler, C. Potential gains from water rights trading in the Aral Sea Basin. Agric. Water Manag. 2015, 152, 41-56. [CrossRef]

12. Young, M.D. Water Rights: An Ecological. Economics Perspective; Australian Agricultural and Resource Economics Society: Vermont, Victoria, Australia, 1997.

13. Hearne, R.R. Institutional and organizational arrangements for water markets in Chile. In Markets for Water; Easter, K.W., Rosegrant, M.W., Dinar, A., Eds.; Springer: Boston, MA, USA, 1998; pp. 141-157.

14. Simpson, L. Are" Water Markets" a Viable Option? Financ. Dev. 1994, 31, 30.

15. Marino, M.; Kemper, K.E. Institutional Frameworks in Successful Water Markets: Brazil, Spain, and Colorado, USA; The World Bank: Washington, DC, USA, 1999.

16. Khan, S.; Dassanayake, D.; Mushtaq, S.; Hanjra, M.A. Predicting water allocations and trading prices to assist water markets. Irrig. Drain. 2009, 59, 388-403. [CrossRef]

17. Meinzen-Dick, R.S. Groundwater markets in Pakistan: Institutional development and productivity impacts. In Markets for Water; Easter, K.W., Rosegrant, M.W., Dinar, A., Eds.; Springer: Boston, MA, USA, 1998; pp. 207-222.

18. Shah, T. Groundwater Markets and Irrigation Development; Oxford University Press: Oxford, UK, 1993.

19. Archibald, S.O.; Renwick, M.E. Expected transaction costs and incentives for water market development. Nat. Resour. Manag. Policy 1998, 15, 95-117.

20. Bauer, C.J. Against the Current: Privatization, Water Markets, and the State in Chile; Springer: New York, NY, USA, 1998.

21. Lee, T.R.; Jouravlev, A. Prices, Property and Markets in Water Allocation; Naciones Unidas Comisión Económica para América Latina y el Caribe: Santiago de Chile, Chile, 1998.

22. Wang, Y. A simulation of water markets with transaction costs. Agric. Water Manag. 2012, 103, 54-61. [CrossRef]

23. Liu, Y.M.; Luo, B.L. Effects of Tradeable Water Rights on Farmers' Irrigation Water use Behaviour. Math. Pract. Theory 2014, 44, 7-14.

24. Habakkuk, H.J. American and British Technology in the 19th Century; Cambridge University Press: Cambridge, UK, 1962.

25. Nordhaus, W.D. Productivity Growth and the New Economy. Brookings Pap. Econ. Act. 2002, 2002, $211-265$. [CrossRef] 
26. Rigby, D.; Alcon, F.; Burton, M. Supply uncertainty and the economic value of irrigation water. Eur. Rev. Agric. Econ. 2010, 37, 97-117. [CrossRef]

27. Bjornlund, H.; McKay, J. Do Permanent Water Markets Facilitate Farm Adjustment and Structural Change Within Irrigation Communities? Rural Soc. 1999, 9, 555-572. [CrossRef]

28. Amsalu, A.; De Graaff, J. Determinants of adoption and continued use of stone terraces for soil and water conservation in an Ethiopian highland watershed. Ecol. Econ. 2007, 61, 294-302. [CrossRef]

29. Anley, Y.; Bogale, A.; Haile-Gabriel, A. Adoption decision and use intensity of soil and water conservation measures by smallholder subsistence farmers in Dedo district, Western Ethiopia. Land Degrad. Dev. 2007, 18, 289-302. [CrossRef]

30. Bekele, W.; Drake, L. Soil and water conservation decision behavior of subsistence farmers in the Eastern Highlands of Ethiopia: A case study of the Hunde-Lafto area. Ecol. Econ. 2003, 46, 437-451. [CrossRef]

31. Saleth, R.M. Water Markets in India: Extent and Impact. In Water Markets for the 21st Century; Easter, K.W., Huang, Q., Eds.; Springer: Dordrecht, The Netherlands, 2014; pp. 239-261.

32. Vaux, H.J., Jr.; Howitt, R.E. Managing water scarcity: An evaluation of interregional transfers. Water Resour. Res. 1984, 20, 785-792. [CrossRef]

33. Becker, N. Value of moving from central planning to a market system: Lessons from the Israeli water sector. Agric. Econ. 1995, 12, 11-21. [CrossRef]

34. Garrido, A. A mathematical programming model applied to the study of water markets within the Spanish agricultural sector. Ann. Oper. Res. 2000, 94, 105-123. [CrossRef]

35. Garrick, D.; Whitten, S.M.; Coggan, A. Understanding the evolution and performance of water markets and allocation policy: A transaction costs analysis framework. Ecol. Econ. 2013, 88, 195-205. [CrossRef]

36. Manuel, A.; Jos, A.G.; Mez-Lim, N.M. Local Water Markets for Irrigation in South Spain: A Multi-criteria Approach. Aust. J. Agric. Resour. Econ. 2002, 46, 21-43.

37. Ge, M.; Wu, F.-P.; You, M. Initial Provincial Water Rights Dynamic Projection Pursuit Allocation Based on the Most Stringent Water Resources Management: A Case Study of Taihu Basin, China. Water 2017, 9, 35. [CrossRef]

38. Bai, B. Research on the countermeasures of sustainable use and development for water resource in China. Future Dev. 1997, 10, 10-13.

39. Heaney, A.; Hafi, A.; Beare, S.; Wang, J.X. Water reallocation in northern China: Towards more formal markets for water. In Agricultural Water Management in China; Willett, I.R., Gao, Z., Eds.; Australian Center for International Agricultural Research: Canberra, Australia, 2006.

40. Li, H.; Hu, J.L. Influencing factors of water right transfer in Yellow River basin based on two-sector mode. J. Econ. Water Resour. 2011, 29, 27-34.

41. Bolognesi, T.; Nahrath, S.; Cleveland, C.J. Environmental governance dynamics: Some micro foundations of macro failures. Ecol. Econ. 2020, 170, 106555. [CrossRef]

42. Hearne, R.R.; Easter, K.W. The economic and financial gains from water markets in Chile. Agric. Econ. 1997, 15, 187-199. [CrossRef]

43. Montero, J.-P. Marketable pollution permits with uncertainty and transaction costs. Resour. Energy Econ. 1998, 20, 27-50. [CrossRef]

44. Stavins, R.N. Transaction Costs and Tradeable Permits. J. Environ. Econ. Manag. 1995, 29, 133-148. [CrossRef]

45. Ostrom, E. Understanding Institutional Diversity; Princeton University Press: Princeton, NJ, USA, 2009.

46. Weisstein, E.W. Cubic Formula. Available online: https://mathworld.wolfram.com (accessed on 17 July 2017).

47. China Water Web. Industrial Water Price. Available online: http://www.h2o-china.comn (accessed on 10 July 2017).

48. Inner Mongolia Autonomous Region Government. Standard of Water Resources Fees. Available online: http://www.wulanchabu.gov.cn/information/wlcbzfw7011/msg948735058492.html (accessed on 17 July 2017).

49. Water Conservancy Department of Inner Mongolia Autonomous Region Government. Inner Mongolia Water Resources Bulletin 2004. Available online: http://slt.nmg.gov.cn/xxgk/jcms_files/jcms1/web2/site/col/col56/ index.html (accessed on 17 July 2017).

50. Water Conservancy Department of Inner Mongolia Autonomous Region Government. Inner Mongolia Water Resources Bulletin 2014. Available online: http://slt.nmg.gov.cn/xxgk/jcms_files/jcms1/web2/site/col/col56/ index.html (accessed on 17 July 2017). 
51. Wu, J. Analysis of Water Market Institution under the Social-Ecological System. Master's Thesis, Tsinghua University, Beijing, China, 2015.

52. Wang, H.; Lall, S. Valuing water for Chinese industries: A marginal productivity analysis. Appl. Econ. 2010, 34, 759-765. [CrossRef]

53. Xi, Q. Study on Evaluation and Technical Efficiency of Industrial Water Saving Projects. Ph.D. Thesis, Tianjin University, Tianjin, China, 2011.

54. Xu, M. [Raw Database] The Impacts of Arable Land Per Farmer on Water Markets in China. 2020. Available online: https://zenodo.org/record/4285502\#.X82o5rMRWUm (accessed on 6 December 2020).

55. Cason, T.N.; Gangadharan, L. Transactions Costs in Tradable Permit Markets: An Experimental Study of Pollution Market Designs. J. Regul. Econ. 2003, 23, 145-165. [CrossRef]

56. Pender, J.L.; Kerr, J.M. Determinants of farmers' indigenous soil and water conservation investments in semi-arid India. Agric. Econ. 1998, 19, 113-125.

57. Jara-Rojas, R.; Bravo-Ureta, B.E.; Diaz, J.M.C. Adoption of water conservation practices: A socioeconomic analysis of small-scale farmers in Central Chile. Agric. Syst. 2012, 110, 54-62. [CrossRef]

58. Huang, S.X. Research on the California Water Rights System. Master's Thesis, Xiamen University, Xiamen, China, 2014.

59. Dwyer, G.; Loke, P.; Appels, D.; Stone, S.F.; Peterson, D.C. Integrating Rural and Urban Water Markets in South East Australia: Preliminary Analysis. Productivity Commission OECD Conference Paper. 2005. Available online: https://ssrn.com/abstract=883562 (accessed on 6 December 2020). [CrossRef]

60. Gorton, M.; Sauer, J.; Peshevski, M.; Bosev, D.; Shekerinov, D.; Quarrie, S.A. Water Communities in the Republic of Macedonia: An Empirical Analysis of Membership Satisfaction and Payment Behavior. World Dev. 2009, 37, 1951-1963. [CrossRef]

61. Meinzen-Dick, R. Beyond panaceas in water institutions. Proc. Natl. Acad. Sci. USA 2007, 104, 15200-15205. [CrossRef]

62. Ostrom, E. Governing the Commons: The Evolution of Institutions for Collective Action; Cambridge University Press: Cambridge, UK, 1990.

63. Wang, Y.; Wan, T.; Biswas, A.K. Structuring water rights in China: A hierarchical framework. Int. J. Water Resour. Dev. 2017, 34, 418-433. [CrossRef]

64. Wang, Y.; Chen, S. Breaking the dilemma of agricultural water fee collection in China. Hydrol. Res. 2014, 16, 773-784. [CrossRef]

Publisher's Note: MDPI stays neutral with regard to jurisdictional claims in published maps and institutional affiliations.

(C) 2020 by the authors. Licensee MDPI, Basel, Switzerland. This article is an open access article distributed under the terms and conditions of the Creative Commons Attribution (CC BY) license (http://creativecommons.org/licenses/by/4.0/). 